\title{
COMPARATIVE TRANSNATIONAL CIVIL PROCEDURE: EXCLUSIVE AND EXORBITANT CIVIL JURISDICTION IN BRAZIL, UNITED STATES OF AMERICA AND EUROPEAN UNION
}

\section{PROCESSO CIVIL INTERNACIONAL COMPARADO: EXCLUSIVIDADE E EXORBITÂNCIA DE JURISDIÇÃO NO BRASIL, NOS ESTADOS UNIDOS DA AMÉRICA E NA UNIÃO EUROPEIA}

AUGUSTO JAEGER JUNIOR

Doutor em Direito Comunitário pela UFRGS e mestre em Direito Internacional pela Universidade Federal de Santa Catarina (UFSC). Professor Permanente do Programa de Pós-Graduação em Direito da Universidade Federal do Rio Grande do Sul (UFRGS). Bolsista de Produtividade em Pesquisa do Conselho Nacional de Desenvolvimento Científico e Tecnológico (CNPq). E-mail: augusto.jaeger@ufrgs.br

\section{NICOLE RINALDI DE BARCELLOS}

Doutoranda e Mestre pelo Programa de Pós-Graduação em Direito da Universidade Federal do Rio Grande do Sul (PPGDir./UFRGS). Especialista em Direito Internacional pela Universidade Federal do Rio Grande do Sul (UFRGS). Bolsista da Coordenação de Aperfeiçoamento de Pessoal de Nível Superior (CAPES). E-mail: nicoledebarcellos@gmail.com

\section{ABSTRACT}

This study aims to explore the rules on the jurisdiction of courts in the Brazilian, North-American and European Union legal systems, and their reasonableness, in order to determine if they contain characteristics of exorbitance and exclusivity in the exercise of jurisdiction, and to compare them. Legislators in different legal orders tend to enact norms with comprehensive grounds for jurisdiction, with the intention of 
protection of their own interests, which are not always consistent with the best interest of the parties or the proximity of the case with the forum. To develop the mentioned objectives, the study was divided into two parts. In the first section, the general and special rules of jurisdiction in the Brazilian, North-American and European Union legal systems are explored. In the second section, the exorbitance and exclusivity of jurisdiction are analyzed, in order to propose a comparison between the three systems. In the study, we identified exorbitant and exclusive jurisdiction rules in all legal systems analyzed, which have negative consequences on the access to justice of individuals. Rules on jurisdiction should be instruments for the promotion of transnational justice and therefore exorbitant and exclusive rules on jurisdiction should be limited.

KEYWORDS: International civil procedure; International civil jurisdiction; Reasonable jurisdiction; Exclusive and exorbitant civil jurisdiction.

\section{RESUMO}

Este estudo pretende explorar as regras de jurisdição internacional nos sistemas jurídicos do Brasil, dos Estados Unidos da América e da União Europeia, e a sua razoabilidade, com fins de desvendar se eles contêm características de exorbitância e exclusividade no exercício da jurisdição, comparando-as. Legisladores em diferentes ordens jurídicas tendem a promulgar normas com amplos fundamentos para jurisdição, com a intenção de proteger seus próprios interesses, que nem sempre são compatíveis com o melhor interesse das partes ou com a proximidade do caso com o foro. Para desenvolver os objetivos propostos, o estudo foi dividido em duas partes. Na primeira seção, são analisadas as regras gerais e especiais de jurisdição dos sistemas jurídicos do Brasil, dos Estados Unidos da América e da União Europeia. Na segunda seção, aborda-se exorbitância e exclusividade da jurisdição, com fins de propor uma comparação entre os três sistemas nesta matéria. Com o estudo, identificamos regras de jurisdição exorbitantes e exclusivas em todos os sistemas legais analisados, que possuem consequências negativas ao acesso à justiça dos indivíduos. As regras sobre a jurisdição devem ser instrumentos para a 
promoção da justiça transnacional e, portanto, as regras exorbitantes e exclusivas sobre jurisdição devem ser limitadas.

PALAVRAS-CHAVE: Processo civil internacional; Jurisdição civil internacional; Jurisdição razoável; Jurisdição civil exclusiva e exorbitante.

\section{INTRODUCTION}

This study aims to explore the Brazilian, North-American and European Union legal systems in what concerns the jurisdiction of the courts, and their reasonableness, in order to determine if they contain exorbitant or exclusive rules, and to compare them. Legislators tend to enact norms with comprehensive grounds for jurisdiction, with the intention of protection of their own interests, which are not always consistent with the best interest of the parties or the proximity of the case with the forum.

The comparison between these legal systems is justified considering that Brazil and United States of America have national regulations, being part of civil and common law families, respectively, and European Union has a supranational regulation, that unifies both civil and common law systems. In addition, both European Union and Brazil have recently enacted legislations on international civil jurisdiction in order to adapt to contemporary impositions of the increase on international litigation, which have reflections on transnational civil procedure.

The internationalization of private relations is a phenomenon that exists as a consequence of the growth of international movements of people (DREYZIN DE KLOR, 2012; FERNÁNDEZ ARROYO, 2006; LEQUETTE, 2012). From the point of view of transnational civil procedural law, this movement is connected to a vertiginous increase in international litigation and the growing importance of reasonable rules regarding the jurisdiction of courts. Every case with international connection has the conflict of jurisdictions at its center, considering that the definition of the competent forum precedes the choice of the applicable law. 
According to Erik Jayme, the changes faced by private international law lead to a growing importance of the conflicts of jurisdictions (1995, p. 47-48). In his turn, Diego Fernández-Arroyo asserts that the conflict of jurisdictions has taken the place of conflict of laws in the core of attention of legislators and doctrine (2006, p. 28-29).

In this sense, the analyzed systems have had legislative innovations in recent years, what shows the intense activity in this area of study. Brazil has enacted in 2015 a new Code of Civil Procedure, which came into force in 2016, as well as the European Union has established in 2012 the Regulation 1215/2012 (Regulation Brussels I Recast), which came into force in 2015. Both legislations contain the rules on the jurisdiction of courts of the respective legal systems in general civil matters.

If on one hand, the notion of jurisdiction based on physical borders is relativized in the light of the internationalization of relations (MICHAELS, 2004, p. 105-130), on the other hand, as a form of protectionism and expansion of power, States tend to expand the limits of their jurisdiction through static rules of direct application that establish the limits of the jurisdiction of the courts, which are sometimes unreasonable. Considering that, the fundamentals of the rules of attribution of jurisdiction should be challenged by an academic investigation, where the primary goal is to understand the content of the norms in the three proposed legal systems.

With this study, we intend to answer the following research questions: considering the Brazil, United States of America and European Union legal systems, do we identify unreasonable rules of jurisdiction? Which are the similarities and differences among them? To develop these questions, the study was divided into two parts. In the first section, the general and special rules of jurisdiction in the Brazilian, North-American and European Union legal systems are explored. Then, in the second section, the exorbitance and exclusivity of jurisdiction in these legal systems are analyzed, in order to compare them.

As theoretical framework, we adopt the work of the authors Diego Fernández Arroyo, concerning exorbitant and exclusive jurisdiction and Paul Lagarde, concerning the principle of proximity in international law. 


\section{PANAROAMA OF INTERNATIONAL CIVIL JURISDICTION RULES IN NATIONAL AND SUPRANATIONAL LEGAL SYSTEMS OF BRAZIL, UNITED STATES OF AMERICA AND EUROPEAN UNION}

The rules on international jurisdiction determine the cases in which a State will be competent to adjudicate a dispute with international connections, relating to persons, facts or property (DORSETT, MCVEIGH, p. 3). Any dispute that encompasses an international connection has the conflict of jurisdictions at its core. This means that the limits of jurisdiction at national and supranational levels are established through rules of international jurisdiction, which define the connecting criteria according to which domestic courts will be based, grounded on internal procedural rules (LIEBMAN, 1976, p. 16; POLIDO, 2013, p. 31-32).

In fact, international jurisdiction is defined as the internal side of sovereignty, because it comprehends cases in which international law is applied internally in a sovereign State (DINH, DAILLIER, PELLET, p. 452) ${ }^{1}$. As Giuseppe Chiovenda states, jurisdiction is the power originated in the sovereignty of the State to analyze and judge disputes within its territory (1969, p. 16-17). Thus, each legal system has its own rules on jurisdiction, proposed according to the national and regional characteristics.

This topic aims to investigate the national systems of Brazil and United States of America, corresponding to the civil and common law traditions (1.1), and the supranational system of the European Union, which encompasses both traditions in one europeanized private international law system (1.2). With that, it will be possible to draw a panorama of the three legal systems.

\footnotetext{
1 And more, from a historical perspective, Costas Douzinas states that for a community to be in common in its sovereignty, relationships amongst its members must be circumscribed in jurisdiction, that means the diction of the law or law's speech and word. DOUZINAS, Costas. The metaphysics of jurisdiction. In: MCVEIGH, 2007, p. 22.
} 


\subsection{INTERNATIONAL CIVIL JURISDICTION IN NATIONAL SYSTEMS: THE CASES OF BRAZIL AND UNITED STATES OF AMERICA}

According to Ugo Rocco, the State is the specific authority for the performance of law and the activity developed by it is the reflection of a public activity with a jurisdictional characteristic (1969, p. 67-68). This means that jurisdictional function is a power emanating from the sovereignty of the State (FERNÁNDEZ ROZAS, SÁNCHEZ LORENZO, 2004, p. 52). In this sense, as stated Frederik Alexander Mann, every state is free to determine the jurisdiction of the judges restrained in their territory, through the edition of procedural rules or case-law (1968, p. 11-12).

In the case of Brazil, a new Code of Civil Procedure was enacted on March $23^{\text {rd }}, 2015$ and entered into force one year after that date, in 2016 (BRASIL, 2015). The code presents innovative norms on concurrent jurisdiction, when the power of a State to decide over a case does not exclude other States to judge it, and also on exclusive jurisdiction, when a State holds the exclusive jurisdiction and no other can legitimately adjudicate the dispute (DEL'OLMO, JAEGER JUNIOR, 2017, p. 66-67).

Brazil is a civil law legal system, which encompasses, according to Kevin Clermont and John Palmer, the Roman idea of jurisdictional restraint in reflection of a spirit of fairness (2006, p. 474-505). The authors state that the adoption of the rule of Actor sequitur forum rei by civil law systems dates back to Justinian and means that the plaintiff follows the forum of the defendant's domicile, and also that jurisdiction is extended in cases of tort, contract and property, when the plaintiff can choose the place of the wrongful conduct.

Considering that, according to Andre de Carvalho Ramos, in the Brazilian rules on jurisdiction can be identified objective and subjective criteria, which denote foreign elements linked to the transnational procedure, defining the grounds for jurisdiction (2018, p. 2016). Foreign elements can be into two categories, which are personal elements, such as domicile, and elements related to the object, such as the place of the act or where the property is located ${ }^{2}$.

\footnotetext{
2 In Portuguese, the classification is named by the elements of "caráter pessoal" and "caráter real". For more, see: MACHADO VILLELA, 1921, p. 598.
} 
The general rules of Brazilian concurrent jurisdiction establish that national authorities are competent when: (i) the defendant is domiciled in Brazil; (ii) the obligation should be fulfilled in Brazil and (iii) the basis of the claim is a fact that occurred, or an act was practiced in Brazil. These standards have been stable along the years, considering the succession of different legislations (JATAHY, 2003; BARBI, 1975, p. 393-399).

On the other hand, the special rules of Brazilian concurrent jurisdiction were introduced in the national legal order by the new Code of Civil Procedure of 2015. Thus, Brazilian judicial authority is competent: (i) to process and adjudicate maintenance actions, when the creditor is domiciled or resident in Brazil or the defendant maintains links in Brazil; (ii) actions resulting from consumer relations, when the consumer has domicile or residence in Brazil and (iii) actions in which the parties have submitted expressly or tacitly to the national jurisdiction.

The rules of Brazilian exclusive jurisdiction also present innovations, considering they expand the scope of jurisdiction. In this sense, national authorities will be exclusively competent to hear actions: (i) relating to immovable property located in Brazil; (ii) in matters of hereditary succession proceed with the confirmation of private will and the inventory and division of property located in Brazil and (iii) in matters of divorce, judicial separation or dissolution of the stable union proceed to the division of property located in Brazil. The themes related to divorce, judicial separation and dissolution of stable union are a novelty of Code of Civil Procedure.

The United States of America legal system, in its turn, comprises a common law system, which encompasses a tradition of connecting jurisdiction to the power attached to sovereignty and the territorial boundaries (FRAGISTAS, 1961, p. 221228; CLERMONT, PALMER, 2006, p. 486). With that in mind, territorial jurisdiction in the United States of America is divided into two basic categories: (i) non-personal, when involving a thing and (ii) personal, when relating to persons (CLERMONT, 2004, p. 92). In these cases, courts acquire civil international jurisdiction through power over the person or thing and admit derogation when the ground is unreasonable or unfair, although the sovereign can naturally choose the self-restraint (CLERMONT, PALMER, 2006, p. 486). And more, the United States of America 
system adopts the doctrine of forum non conveniens, when a court may refuse to take jurisdiction on a certain matter if there is a more appropriate court to adjudicate (See: BRAND; JABLONSKI, 2007). According to Georges Droz, the adopted method adopted is flexible (1991, p. 50).

Kevin Clermont states that jurisdictional law in the United States of America has the reputation of being overreaching and complicated, but a closer analysis shows that its content is defensible (2004, p. 91). And more, according to Arthur Lenhoff, the United States of America is one of the few federalist countries where each member state has a legal system of its own, that regulates disciplines relating to conflicts of law such as international and interstate jurisdiction (1964, p. 8). So, in the North-American system the jurisdiction is limited by the Constitution, as it is interpreted by the Supreme Court, and shall be exercised within these limits (TSCHEINER, 2014, p. 259). Even with limitations, according to Cedric Ryngaert, the extraterritorial exercise of jurisdiction in the United States of America is criticized, because of the cases in which the country extends the long arm of national law (2015, p. 8).

Therefore, in the North-American system, the court undertakes a civil adjudication when it has territorial authority to adjudicate, confining the place of litigation. The traditional basis of jurisdiction in the United States of America are reasoned on the physical presence of the defendant or thing at the time of service of process $(1964$, p. 8). The constitutional limitation for this jurisdiction can be traced back to the case Pennoyer v. Neff (1978), when the Supreme Court relied on two principles, by reasoning that they were equally applicable to several states: (i) every State possesses jurisdiction over persons and property within its territory, and (ii) no State can exercise direct jurisdiction and authority over persons and property without its territory (CLERMONT, 2004, p. 91; BORN, 1987, p. 2; TSCHEINER, 2014, p. 261).

But, according to Gary Born, it was in the case International Shoe Co. $v$. Washington (1945), where the Supreme Court shaped the contemporary rule that a state court can exercise jurisdiction over persons located outside the territory, but only if the defendant has minimum contact with the forum state, so that the maintenance of the claim does not offend the traditional notions of fair play and 
substantial justice (1987, p. 2). This case preserved Pennyover territorial foundations, but expanded jurisdiction considering the minimum contact rule.

The cited precedents involved jurisdiction in domestic cases in the United States of America, but the International Shoe minimum contact rule was subsequently applied to international jurisdiction cases such as Helicopteros Nacionales de Colombia S.A. v. Hall and Perkins v. Benquet Consolidated Mining $C o$. , which involved due process challenges to a state court jurisdiction over a foreign person (BORN, 1987, p. 6).

Therefore, in the North-American system, as general rule, the forum acquires jurisdiction in civil cases through the power of binding persons or things in the boundaries of its territory (CLERMONT, 2004, p. 90-96). But decisional and statutory law have given the courts in the United States of America a freedom to exercise jurisdiction over people that do not reside in the country and also foreign corporations, what is given with basis on the due process clause, that requires only a minimum contact with the territory of the forum (LENHOFF, 1964, p. 8). On the other hand, while personal jurisdiction is more expanded, non-personal jurisdiction still requires the physical presence of the thing to constitute minimum contact.

\subsection{INTERNATIONAL CIVIL JURISDICTION IN A REGIONAL SUPRANATIONAL SYSTEM: THE CASE OF THE EUROPEAN UNION}

Private international law discipline in the European Union has been through a process of Europeanization, which corresponds to a gradual withdrawal of the use of autonomous domestic legislation of the member states of the European Union, in order to allow the adoption of supranational instruments containing conflict rules (JAEGER JUNIOR, 2012, p. 27; JAEGER JUNIOR, 2016). This is the case of the jurisdiction of the courts in civil and commercial matters, which was regulated firstly by the 1968 Brussels Convention (already revoked) and today is completely europeanized by the Brussels I Recast Regulation (Regulation 1215/2012) (EUROPEAN UNION, 2012).

European Union has a supranational system that regulates the jurisdiction of the courts of the State-members, which is applicable to the cases with international 
connection. The current article 81 of the Treaty on the Functioning of the European Union (TFEU) establishes in the European legal system the competence to standardize the rules of private international law, such as the provisions on jurisdiction of the courts.

With basis on that article of the TFEU, since the early twenty first century, several regulations were enacted by the European Union in two different areas of private international law, namely, material and procedural law. At first, the regulations approached separately material and procedural law, but most recent ones comprise in the same instrument both procedural and material private international law. In the matter of jurisdiction, today, five Regulations are into force, which are the Brussels I Recast, for civil and commercial matters, the Brussels II-bis, for matrimonial matters and parental responsibility, the Brussels III, for maintenance obligations, the Regulation no 650/2012, for successions, and the Regulations no 1103 and $1004 / 2016$ for matrimonial property regimes and the effects of registered partnerships.

For its broad scope, the Regulation № 1215/2012 (Brussels I Recast) was chosen to be analyzed on detail by this study. This regulation has applicability from 10 December 2015, in the 28 State Members of the European Union, on the theme jurisdiction and the recognition and enforcement of judgments in civil and commercial matters, considering it represents the most important instrument regulating international civil proceedings in the European Union.

The rules of jurisdiction of the courts existent in the Regulation 1215/12 are bilateral and distribute the competences in civil and commercial cases among the state members of the European Union. The general norm of conflict on jurisdiction establishes the forum of the domicile of the defendant, irrespective of his or her nationality, a provision that issues advantages for both plaintiff and defendant since it is reasonable in relation to the demand procedural conditions, with pragmatic foundations (FERNÁNDEZ ARROYO, 2006, p. 138-142). That is, the rule of the habitual domicile of the defendant represents the center of the life and the place where the defendant has chosen to voluntarily establish his or her center of interests on a stable basis (CARRASCOSA GONZÁLES, 2015, p. 18). 
There are also some special rules on jurisdiction that correspond to twelve specific situations, divided into substantive and procedural. Seven substantive issues are raised by the norm, relating to contracts, non-contractual matters, damages based on criminal offenses, recovery of cultural objects, branch operation, trust, remuneration for assistance or rescue. Four procedural questions are raised, cases involving multiple defendants and interconnected demand claims, intervention by third parties, counterclaims and real property rights (STONE, 2011, p. 75-122). These special rules proposed by the European Union legislature are aimed at the search for a close connection of the jurisdiction with the object of dispute.

In addition, the Brussels I Recast provides for special jurisdiction rules that determine the protection of the most vulnerable parties in cases involving insurance, consumer contracts and individual contracts of employment. Here, we observe that in private international law there is a growing importance of protection forum, as envisaged in the European Union, aimed at reestablishing the balance of a legal relationship through the protection of vulnerable parties (LOWENFELD, 1994, p. 7778; FERNÁNDEZ ARROYO, 2006, p. 43).

Regarding insurance, the insurer may be sued in the domicile at the place where the policyholder, the insured or a beneficiary is domiciled or where the main action has been brought, in the case of the insured. In the case of consumers, proceedings may be brought either in the courts of the member state in which the defendant is domiciled or in the place where the consumer is domiciled, and the parties may derogate jurisdiction in specific cases. With regard to individual employment contracts, the employee may sue where the employer is domiciled, where he or she is employed or where the establishment that hired him is located. All the rules mentioned are general rules of protection forums.

Exclusive rules of jurisdiction provide for situations in which only one member state has jurisdiction over a particular claim, irrespective of the domicile of the parties, where the application of the Regulation is exclusive and non-derogable. The recognition of an exclusive competence refers to the identification of an interest of the State, in order to justify the exclusivity of a forum (VON MEHREN, 1983, p. 119). Within the European Union, exclusive powers are binding on rights in rem in immovable property, on the validity of the constitution, nullity or dissolution of 
companies or other legal persons or associations of natural or legal persons, on the registration of intellectual property and on the enforcement of decisions.

Having examined the normative structure of international rules on jurisdiction in the European Union, in civil and commercial matters, as well as the Brazilian and United States of America national rules, we can provide a partial conclusion to this study. Despite of being national and supranational systems, respectively, Brazil and the European Union adopt for civil cases the general conflict norm of jurisdiction of the domicile of the defendant, as a filiation to the traditional maxim of civil law, and both have special rules on jurisdiction. The domicile of the defendant is a desirable ground for jurisdiction and the paradigm of reasonable jurisdiction, considering it is concept with a high degree of factual content, which indicates the place in which a person can be found with a considerable margin of probability and which at the same time should enable to exercise his rights of defense (FERNÁNDEZ ARROYO, 2006, p. 44-45). At the same time, the United States of America adopts the rule of minimum contact of the person and the thing with the North American territory and admits derogation when the ground is unfair, which also provides an idea of accordance to the principle of proximity and reasonableness (DROZ, 1991, p. 54-60).

Based on these considerations, the second part of the study investigates the grounds for reasonableness of jurisdiction in these three legal orders, with an analysis of the above cited norms, and the comparison of the identified cases of exclusive and exorbitant jurisdiction.

\section{REASONABLE JURISDICTIONS IN CIVIL INTERNATIONAL PROCEDURE: EXORBITANCE AND EXCLUSIVITY IN BRAZIL, UNITED STATES OF AMERICA AND EUROPENA UNION}

Jurisdiction is a concept based on the notion of sovereignty of the States, and the idea that they have autonomy to choose the content of their own legal systems and to propose the norms that should be followed. In that sense, as far as international order concerns, Martti Koskenniemi states that the principle of noninterference is an instrument to prevent encroachment on State sovereignty (2005, p. 
93). Private international law rules on jurisdiction of the courts are based on this premise, as States themselves establish their own limits to jurisdiction.

Besides that, legal orders interests are relevant and often influential in determining whether jurisdiction exists and whether it ought to be exercised, but, according to Mary Keyes, unfortunately, these influences are often suppressed (2007, p. 124). Some rules on international jurisdiction are enacted by legislators with basis on criteria that do not always observe the best interest of the parties or the proximity of the case with the forum, but with the intention of protection of their own interests. Yet jurisdiction should be an instrument in the promotion of transnational justice, when individuals should have full access to justice.

Based on that situation, some authors have dedicated their researches to delimit the values that would reflect the justice or reasonableness of a certain norm of attribution of jurisdiction, especially in the case of elaboration of conflict rules by legal orders. In this topic we aim to propose a definition of exorbitance and exclusivity in jurisdiction (2.1), and with basis on that, to identify these norms in the legal systems presented and to compare them (2.2).

\subsection{DEFINITION OF REASONABLE JURISDICTION IN INTERNATIONAL CIVIL PROCEDURE LAW: EXORBITANCE AND EXCLUSIVITY AND THE IMPORTANCE OF PROXIMITY, BALANCE AND COMITY}

The reason why legal orders adopt certain rules of attribution of international jurisdiction is always a relevant question to the private international law discipline, as the justifications may lay, on one side, on the promotion of transnational access to justice, protection of individuals or minorities, or proximity of the dispute with the forum, and, on the other side, the protection of national interests, with political or economic order, the maintenance of sovereignty, among others.

According to Bruno Simma and Andreas Müller, even though States aspire to have legal systems with a comprehensive regulation regarding jurisdiction, not every nexus provided in their regulations is accepted in international law as grounds for jurisdiction (2012, p. 37). Practical and effectiveness reasons, as well as respect for essential principles of the international, should lead to a limitation of the volume of 
international cases in which the jurisdictional power of a legal system should be exercised (FERNÁNDEZ ROZAS, SÁNCHEZ LORENZO, 2004, p. 53-54). With that in mind, some authors have identified parameters for the elaboration of jurisdiction rules, as seen below.

Paul Lagarde states that the proximity of the forum with the cause should be the leading element to justify the elaboration of conflict rules, through the identification of three grounds for the exercise of jurisdiction: (i) the relationship between subject and State as a source of justice; (ii) the coercion power of the State over a person located in its territory or assets and; (iii) considerations of convenience, fairness and justice $\left(1986\right.$, p. 127) ${ }^{3}$. Considering this third ground, the author describes the circumstances related to a fair jurisdiction, when: (i) it is founded on closer links between the parties and the forum, irrespective of the subject of the dispute (domicile, habitual residence, business center); (ii) the links between the litigation and the forum from the procedural point of view (proximity of evidence); (iii) and the links of the dispute regarding the merits of the matter to be discussed (LAGARDE, 1986, p. 127).

Diego Fernández Arroyo divides the arguments of justification to jurisdiction rules into four (2006, p. 53-70): (i) political and economic arguments, which reflect the interests of the states; (ii) substantive legal arguments, which relate to the interest of the parties; (iii) pragmatic arguments, which deal with interests linked to international relations and; (iv) formal legal arguments dealing with the interests of legal orders. According to the author, the basis of a reasonable jurisdiction is the principle of proximity between the case and the court. Paolo Picone states that there is a growing importance of the principle of proximity in the contemporary systems of conflict of law, which leads to a closer to the case interpretation, with objective and tangible criteria (1999, p. 79). To sum up, the three mentioned authors point out that the proximity of the case with the court denotes justice or reasonableness of jurisdiction.

Apart from proximity, another important factor is highlighted by Andreas Lowenfeld, which is the balance between the parties in the procedural relation (1994, p. 77-78). That is, the favoring of only one of the parties would render the jurisdiction

${ }^{3}$ Paul Lagarde uses the classification from Von Mehren. In: VON MEHREN, 1983, p. 279-340. 
unreasonable, such as the absence of proximity. Nonetheless, there is a growing importance of protection forums, which have the function of favoring the vulnerable part in a legal relationship, restoring the balance, such as maintenance and consumer relations (FERNÁNDEZ ARROYO, 2006, p. 43), considering the human rights and its gradual transformation into one of the cornerstones of private international law (ARAUJO, 2018).

A third criterion is presented by Cedric Ryngaert, which is the principle of international comity in order to restrain the excessive exercise of jurisdiction (2015, p. 147-187). According to the author, it would limit the reach of the law of a particular State by requiring that States recognize the laws of States with a stronger link with the case, and thus, that States with a weaker link with the case do not apply their own laws. But comity is discretionary and non-binding, and might not be used when relevant political and economic interests of a State are at stake.

Considering that the principle of proximity, the balance between the parties and the principle of international comity compose a reasonable jurisdiction, exorbitance and exclusivity are identified when these criteria are not observed. Reasonable jurisdiction is an essential principle of international civil procedural law, which provides that a transnational case should only be adjudicated by the courts with reasonable connection to the subject matter of the dispute (ARAUJO, 2018). While there is concern about access to justice by individuals, States should avoid adopting internal procedural rules that establish criteria of connection with jurisdictions that are unreasonable or even exorbitant (RECHSTEINER, 2016, p. 277).

On one hand, cases of exorbitant jurisdiction in civil matters include those situations in which concurrent jurisdiction is validly exercised within a territory, but it remains unfair to the parties (CLERMONT, PALMER, 2006, p. 474), such as: (i) the nationality of the defendant; (ii) the existence of property of the defendant in the forum; and (iii) the existence of business of the defendant on the forum (FERNÁNDEZ ARROYO, 2006, p. 138-160). In the concurrent jurisdiction, reasonableness is connected to certain limits, which, in addition to the substantive proximity of the dispute with the forum, relate, for example, to respect for equality 
between the parties and the choice of forum through party autonomy (LAGARDE, 1986, p. 138-142).

On the other hand, exclusive jurisdiction must necessarily imply the identification of a reasonable interest of the State in requiring such exclusivity of jurisdiction (VON MEHREN, 1983, p. 119). Diego Fernández Arroyo argues that the strong interest of a legal order in a particular case is not automatically converted in exclusivity, just as the close link to the case does not solve the problem of jurisdiction (2006, p. 90). Many States attract the jurisdiction of a certain case with sensitive economic relevance based only on arguments of juridical tradition, that often surpasses reasonableness.

Considering that, for what the criteria of connection to the jurisdiction are concerned, domicile or habitual residence of the defendant have a clear proximity to the forum. They represent the paradigm of a reasonable jurisdiction, as long as they are based on a pragmatic reason: these forums represent the center of life of the defendant, the place where the interested party voluntarily fixed its center of interests in a stable character (FERNÁNDEZ ARROYO, 2006, p. 39-41; CARRASCOSA GONZÁLES, 2015, p. 18). On the other hand, rules exclusive jurisdiction should be an exception, based on reasonable grounds and interests. We now analyze the reasonableness of the Brazilian, North American and European Union Rules on jurisdiction.

\subsection{EXORBITANT AND EXCLUSIVE INTERNATIONAL JURISDICTION RULES IN BRAZIL, THE UNITED STATES OF AMERICA AND THE EUROPEAN UNION: GROUNDS FOR COMPARISON?}

According to Kevin Clermont and John Palmer, nationals tend to overlook the excesses of their own countries over the delimitation of national jurisdiction (2006, p. 475). With that in mind and given the existent rules of international jurisdiction in the civil procedure of Brazil, United States of America and European Union, the grounds of jurisdiction chosen by legislators must be analyzed, so that an indication as to their reasonableness can be reached. 
In the Brazilian system, with respect to concurrent jurisdiction, the extension proposed in the new Code of Civil Procedure regarding maintenance actions expressly establishes that the Brazilian court will have jurisdiction when the defendant has business in Brazil. A superficial analysis of this device leads to the conclusion that this is a hypothesis of exorbitant jurisdiction, however, it can be justified as a forum for protection.

Regarding exclusive jurisdiction, a provision establishes that the Brazilian court will be exclusively competent to process and adjudicate demands for division of property located in Brazil, movable or immovable, regardless of the principle of proximity. Here we observe that the Code of Civil Procedure did not adopt a reasonable criterion, because before the enactment of the code, the movable property division inter vivos, even if proceeded by a foreign authority, was considered legitimate in the cases that there was agreement between the parties (ARAUJO, 2018). The practical consequence of the application of this article is serious since the parties will be forced to process the division of property directly in Brazil, regardless of the value or importance of the property, and if it is carried out in the foreign court, it will not be feasible in the national territory (CASTRO, 1997, p. 256). This is a major regression in Brazilian legislation, as it is a new and unjustified case of international exclusive jurisdiction in Brazil (MEINERO, 2016, p. 284-296). Thus, it should have been adopted a more reasonable criterion, which at least specified that divorces with property of lower value or of lower level are not exclusively connected to Brazilian jurisdiction.

In the United States of America system three situations of exorbitance are identified, according to the hypotheses proposed by Kevin Clermont and John Palmer (2006, p. 477-482). Firstly, there is the case of transient jurisdiction, when a momentary presence of the defendant can justify the exercise of jurisdiction, even if the claim is unrelated to that presence ${ }^{4}$, with the limit of being minimally connected to the territory. Secondly, the attachment jurisdiction, used in cases when the plaintiff has a personal claim against the defendant and seeks to attach to it the property of the defendant, without adopting the personal jurisdiction, that is, using the non-

${ }_{4}$ Burnham v. Superior Court satisfied the reasonability test for the transient jurisdiction merely because of a historical pedigree. CLERMONT; PALMER, 2006, p. 478. 
personal jurisdiction in a dispute over the defendant ${ }^{5}$. Thirdly, the doing business jurisdiction, when the exercise of jurisdiction is justified when individual or corporation that practices state-directed acts, but only to personal claims over it, unrelated to the activities $^{6}$.

In the European Union legal system, Diego Fernández Arroyo highlights that since exorbitant forums were identified in the autonomous legal systems of the member states, the supranational legislation has distanced from this pattern, in order to value the access of justice and reasonableness (2004, p. 59-79). But, according to the author, this protection is valid only in the cases in which the person is domiciled in the European Union territory, so the situation of non-domiciled parties is of clear inequity. Another situation relates to the exclusive jurisdiction for societies, intellectual property and real state, which are not present on other regulations, making possible the argument that this system is completely feasible without it.

In comparison of three legal systems analyzed, we can find clear similarities, considering that the exorbitant jurisdiction comprises the cases in which jurisdiction is legal, but unreasonable in relation to the parties (CLERMONT, PALMER, 2006, p. 474), and is clearly present in the legal systems of Brazil, United States of America and European Union. All the legal systems observed demonstrate certain levels of exorbitance, each one with different degrees, depending on how the clauses are applicable by the courts.

Here, we especially highlight the United States of America system, that can justify broad grounds for jurisdiction with basis on the minimum contact doctrine. This flexible system is opened for the decision on the courts that excessively broadens national jurisdiction. On the other hand, both Brazil and European Union have protection forums that might appear unreasonable at first sight, but are justified considering the promotion of balance in the procedural relation, such as the case of maintenance and consumer, insurance and labor law, respectively.

\footnotetext{
${ }^{5}$ Harris $v$. Balk proposed that the plaintiff could invoke attachment jurisdiction by garnishing a debt owing from a third person to the defendant. Later, the understanding was changed by Shaffer $v$. Heitner, being necessary a reasonability test. CLERMONT; PALMER, 2006, p. 479-480.

${ }^{6}$ Perkins v. Benquet Conslidated Mining Co. held that the defendant activities were so extensive in the forum, that they justified the exercise of jurisdiction in an action unrelated to those activities. CLERMONT; PALMER, 2006, p. 481.
} 
Legislated exclusive jurisdiction was identified in Brazil and European Union systems, generally related to real state. This situation has unreasonable and severe impact in the context of the exercise of indirect jurisdiction, thus understood when a transnational situation has been the subject of a foreign decision and should have effect in a given territory through some instrument of international legal cooperation? Here, we highlight that Brazilian legal system has gone further and expanded the provisions of exclusive jurisdiction to property in the cases of marital dissolution, provision that is apart from reasonableness and access to justice.

So, with the observation and comparison of these legal systems, we verify that the cases of exorbitance and exclusivity are not far apart in the world. Both common and civil law, or national and supranational systems, have exorbitant and exclusive rules on jurisdiction. In that sense, the domicile or habitual residence is the jurisdiction which has clear proximity with the forum, based on pragmatic grounds, comprising with reasonableness.

Based on these assumptions, the concepts presented by the doctrine and reported in this article, allied to comparative law, case-law and official documents, we can propose a partial conclusion. The hypotheses of exorbitant and exclusive jurisdiction are found in different jurisdictions. They have negative consequences on the access to justice of individuals, sometimes by denying the access to forum, sometimes by violating rights of defense. When applied to the national and supranational systems, the identification of exorbitant rules may serve as the basis for proposing measures that change definition of conflict of jurisdictions, allowing international disputes to be addressed without undergoing an exacerbated expansion of international jurisdiction, that results in restrictions on access to justice. Rules on jurisdiction should be instruments for the promotion of transnational justice and therefore exorbitant and exclusive rules on jurisdiction should be limited.

\footnotetext{
${ }^{7}$ According to Peter Schlosser, jurisdiction is a manifestation of sovereignty of a State, and must be exercised with a cooperative spirit. SCHLOSSER, 2001, p. 26.
} 


\section{CONCLUSIONES}

In the present study, we explored the rules on the jurisdiction of courts in the Brazilian, North-American and European Union legal systems, in order to identify if and which are the rules that comprise unreasonable jurisdiction, including exorbitant and exclusive jurisdiction. We found out that despite being national and supranational systems, respectively, Brazil and the European Union adopt the general conflict norm of civil jurisdiction of the domicile of the defendant, while the United States of America adopts the rule of minimum contact.

With that in mind, we repeat the research question proposed in the beginning of this study: considering the Brazilian, North American and European Union legal systems, do we identify unreasonable rules of jurisdiction? The answer is positive to all the legal systems studied. Exorbitant jurisdiction is found in each system and legislated exclusive jurisdiction is found in Brazilian and European Union system. A study by academia is important to understand the exacerbated expansion of international jurisdiction, in order to promote legislative changes.

Therefore, we state that the cases of exorbitance and exclusivity are not far apart in the world, being found in different jurisdictions. Rules on jurisdiction should be instruments for the promotion of transnational justice and therefore exorbitant and exclusive rules have negative consequences on the access to justice of individuals. Exorbitant and exclusive rules of jurisdiction should be limited in the legal orders.

\section{REFERENCES}

ARAUJO, Nadia de. Direito Internacional Privado: Teoria e Prática Brasileira. 7. ed. São Paulo: Revista dos Tribunais, 2018. Livro digital.

BERGÉ, Jean-Sylvestre; PORCHERON, Delphine; CERQUEIRA, Gustavo Vieira da Costa. Droit international privé et droit de I'Union Européenne. In: CARREAU, Dominique; LAGARDE, Paul. Répertoire Dalloz de droit international. Paris: Dalloz, 2017. 44 p.

BORN, Gary B. Reflections on judicial jurisdiction in international cases. Georgia Journal of International and Comparative Law, v. 17. Athens, GA: University of Georgia School os Law, 1987. p. 1-44. 
BRAND, Ronald; JABLONSKI, Scott R. Forum non conveniens: history, global practice, and future under the Hague Convention on choice of court agreements. Oxford: Oxford University Press, 2007. 342 p.

BRAZIL. Código de Processo Civil. Lei no 13.105 de 10 de março de 2015. URL: < http://www.planalto.gov.br/ccivil_03/_Ato2015-2018/2015/Lei/L13105.htm>. Access: 23 jan. 2019.

CARRASCOSA GONZÁLES, Javier. El concepto de residência habitual del causante en el reglamento sucesorio europeo. Revista Castellano-Manchega de Ciencias Sociales, n. 19. Azuqueca de Henares: Asociación Castellano-Manchega de Sociología, 2015. p. 15-35.

CARVALHO RAMOS, André de. Curso de Direito Internacional Privado. São Paulo: Saraiva Educação, 2018. 551 p.

CASTRO, Amílcar de. Direito internacional privado. Rio de Janeiro: Forense, 1997. $556 \mathrm{p}$.

CHIOVENDA, Giuseppe. Instituições de direito processual civil. 3. ed. São Paulo: Saraiva, 1969.

CLERMONT, Kevin. The Role of Private International Law in the United States: Beating the Not-Quite-Dead Horse of Jurisdiction. In: CENTER FOR INTERNATIONAL LEGAL EDUCATION. Private Law, Private International Law, \& Judicial Cooperation in the EU-US Relationship. CILE Studies v. 2. Pittsburgh, PA: University of Pittsburgh, 2004. p. 75-114.

CLERMONT, Kevin M.; PALMER, John R. B. Exorbitant jurisdiction. Maine Law Review, v. 58, n. 2. Portland: Univesity of Maine Law School, 2006. p. 474-505.

DEL'OLMO, Florisbal de Souza; JAEGER JUNIOR, Augusto. Curso de direito internacional privado. 12. ed. Rio de Janeiro: Editora Forense, 2017. 388 p.

DINH, Nguyen; DAILLIER, Patrick; PELLET, Alain. Direito Internacional Público: formação do direito, sujeitos, relações diplomáticas, responsabilidade, resolução dos conflitos, manutenção da paz, espaços internacionais. 2. ed. Lisboa: Fundação Calouste Gulbenkian, 2003. 1517 p.

DORSETT, Shaunnagh; MCVEIGH, Shaun. Questions of jurisdiction. In: MCVEIGH, Shaun (Ed.). Jurisprudence of jurisdiction. Oxon: Routledge-Cavendish, 2007. p. 3-18.

DOUZINAS, Costas. The metaphysics of jurisdiction. In: MCVEIGH, Shaun (Ed.). Jurisprudence of jurisdiction. Oxon: Routledge-Cavendish, 2007. p. 21-32. 
DREYZIN DE KLOR, Adriana. Derechos humanos, derecho internacional privado e activismo judicial. Agenda Internacional, v. 19, n. 30. Lima: Pontificia Universidad Catolica del Peru, 2012, p. 119-138.

DROZ, Georges. Regards sur le droit international privé compare. Cours général de droit international privé. Recueil des Cours, t. 229. Dordrecht, Boston, London: Martinus Nijhoff Publishers, 1991. 424 p.

EUROPEAN UNION. Regulation (EU) No 1215/2012 of the European Parliament and of the Council of 12 December 2012 (Recast). URL: <https://eurlex.europa.eu/legal-content/EN/TXT/PDF/?uri=CELEX:32012R1215\&from=EN>. Access: 23 jan. 2019.

FERNÁNDEZ ARROYO, Diego P. Compétence exclusive et compétence exorbitante dans les relations privées internationales. Recueil des Cours, v. 323. La Haye: Académie de Droit International de La Haye, 2006. 259 p.

FERNÁNDEZ ARROYO, Diego P. Competencia internacional exclusiva e exorbitante de los jueces de los Estados-miembros de la Unión Europea: ¿hasta cuándo? Revista Jurídica Anuario del Departamento de Derecho de la Universidad Iberoamericana, n. 34. México: Universidad Nacional Autónoma de México, 2004. p. 59-79.

FERNÁNDEZ ROZAS, José Carlos; SÁNCHEZ LORENZO, Sixto. Derecho internacional privado. 3. ed. Madrid: Civitas Ediciones, 2004. 622 p.

JAEGER JUNIOR, Augusto. Europeização do direito internacional privado: caráter universal da lei aplicável e outros contrastes com o ordenamento jurídico brasileiro. Curitiba: Juruá Editora, 2012. 672 p.

JAEGER JUNIOR, Augusto (Org.). Europeização da parte geral do direito internacional privado: estudos sobre uma codificação do direito internacional privado na União Europeia através de um Regulamento Roma Zero. Porto Alegre: Editora RJR, 2016. 584 p.

JATAHY, Vera Maria Barrera. Do conflito de jurisdições: a competência internacional da justiça brasileira. Rio de Janeiro: Forense, 2003. 239 p.

JAYME, Erik. Identité culturelle et intégration: le droit international privé postmodern. Cours General. Recueil des Cours, v. 251. La Haye: Académie de Droit International de La Haye, 1995. 267 p.

KEYES, Mary. The suppression of state interests in international litigation. In: MCVEIGH, Shaun (Ed.). Jurisprudence of jurisdiction. Oxon: RoutledgeCavendish, 2007. p. 123-134.

KOSKENNIEMI, Martii. From apology to utopia: the structure of international legal argument. Cambridge: Cambridge University Press, 2005. 683 p. 
LAGARDE, Paul. Le principe de proximité dans le droit international privé contemporain. Recueil des Cours, v. 196. La Haye: Académie de Droit International de La Haye, 1986, p. 131-132.

LENHOFF, Arthur. International law and rules on international jurisdiction. Cornell Law Review, v. 50. Ithaca, NY: University of Cornell Law School, 1964. p. 5-23.

LEQUETTE, Yves. Le droit international privé et les droits fundamentaux. In: CABRILLAC, Rémy; FRISON-ROCHE, Marie-Anne; REVET, Thierry (Org.). Libertés et droits fondamentaux. Paris: Dalloz, 2012, p. 115-141.

LIEBMAN, Enrico Tullio. Estudos sobre o processo civil brasileiro. São Paulo: José Bushatsky, 1976.

LOWENFELD, Andreas F. International litigation and the quest for reasonableness. Collected Courses, v. 196. The Hague: Hague Academy of International Law, 1994. $320 \mathrm{p}$.

MACHADO VILLELA, Álvaro da Costa. Tratado elementar teórico e prático de direito internacional privado. Coimbra: Coimbra Editora, 1921. 775 p.

MANN, Frederik Alexander. The doctrine of jurisdiction in international law. Collected Courses, v. 111. The Hague: Hague Academy of International Law, 1968. $162 \mathrm{p}$.

MEINERO, Fernando Pedro. Um novo e injustificado caso de jurisdição internacional exclusiva no novo Código de Processo Civil. In: MENEZES, Wagner (Org.). Direito Internacional em Expansão, v. VIII. Belo Horizonte: Arraes, 2016. p. 284-296.

MICHAELS, Ralf. Territorial Jurisdiction after Territoriality. In: SLOT, Piet Jan; BULTERMAN, Michael. Globalisation and Jurisdiction. Leiden: Kluwer Law International, 2004. p. 105-130.

PICONE, Paulo. Les methods de coordination entre orders juridiques en droit international privé. Recuel des cours, v. 276. La Haye: Académie de Droit International de La Haye, 1999. 296 p.

POLIDO, Fabricio Bertini Pasquot. Direito processual internacional e contencioso internacional privado. Curitiba: Juruá, 2013. 190 p.

RECHSTEINER, Beat Walter. Direito internacional privado: teoria e prática. 18. ed. São Paulo: Saraiva, 2016. 421 p.

ROCCO, Ugo. Tratado de Derecho Procesal Civil, v. 1. Parte General. Bogotá; Buenos Aires: Temis; Depalma, 1969. 411 p.

RYNGAERT, Cedric. A reasonable exercise of jurisdiction. Second Edition. Oxford: Oxford University Press, 2015. 235 p. 
SIMMA, Bruno; MÜLLER, Andreas Th. Exercise and limits of jurisdiction. In: CRAWFORD, James; KOSKENNIEMI, Martti. The Cambridge Companion to International Law. Cambridge: Cambridge University Press, 2012. p. 134-157.

SCHLOSSER, Peter. Jurisdiction and International Judicial and Administrative Cooperation. Collected Courses, v. 284. The Hague: Hague Academy of International Law, 2001. 430 p.

STONE, Peter. EU Private International Law. 2. ed. Cheltenham, UK; Northampton, USA: Edward Elgar, 2011. 562 p.

TSCHEINER, José Maria. Jurisdição territorial nos Estados Unidos da América do Norte e competência internacional e de foro no Brasil. Revista eletrônica de direito processual, v. 13, n. 13. Rio de Janeiro: UERJ, 2014. p. 259-274.

VON MEHREN, Arthur T. Adjudicatory jurisdiction: general theories compared and evaluated. Boston University Law Review, v. 63. Boston: Boston University School of Law, 1983. p. 279-340. 